\title{
Hunger Strike and the Force-Feeding Chair: Guantanamo Bay and Corporeal Surrender
}

Yasmin Ibrahim \& Anita Howarth

\begin{abstract}
Through the biotechnology of the force-feeding chair and the hunger strike in Guantanamo, this paper examines the camp as a site of necropolitics where bodies inhabit the space of the Muselmann - a figure Agamben invokes in Auschwitz to capture the predicament of the living dead. Sites of incarceration produce an aesthetic of torture and the force-feeding chair embodies the disciplining of the body and the extraction of pain while imposing the biopolitics of the American empire on "terrorist bodies". Not worthy of human rights or death, the forcefed body inhabits a realm of indistinction between animal and human. The camp as an interstitial space which is beyond closure as well as full disclosure produces an aesthetic of torture on the racialized Other through the force-feeding chair positioned between visibility and non-visibility. Through the discourse of medical ethics and the legal struggle for rights, the force-feeding chair emerges as a symbol of necropolitics where the hunger strike becomes a mechanism to impede death while possessing and violating the corporeal body.
\end{abstract}

\section{Introduction}

Guantanamo Bay has acquired a symbolic status of the American empire (Roberts 2008) in global biopolitics under the banner of the "war on terror". While there has been a proliferation of criticism, scholarship and commentary on the camp as a site of illegal detention, torture and suffering, this paper examines the corporeal subjugation of those detained through the aesthetic of the force-feeding chair where the pain and predicament of the "trapped bare life" can be performed (Protevi 2009). Guantanamo Bay has been classified as a "black hole" for being beyond legal jurisdiction yet constantly tested through the American judiciary. Couched through a non-visibility where both time and space can be suspended infinitum for the inmates, the camp is nevertheless produced and performed through legal and medical discourses and these slippages provide an insight into the camp, enacting it as an interstitial space beyond closure and equally full disclosure. The force-feeding chair produces an aesthetic conjoining it with a mass spectacle to perform American power despite Guantanamo Bay being hidden and not directly visible.

Guantanamo Bay, while inaccessible to public gaze, has been narrated through a different array of instruments, from personal testimonies and media representations, to legal cases challenging ill treatment and illegal detention, and equally through ethical-medical discourses which challenge the practices in the camp. As such, the site is narrated through a social imaginary, 
and equally through its clandestine invisibility. This interstitial nature of Guantanamo Bay then produces an aesthetic through its implements of control and incursions over the body of the Other. In this paper, we deconstruct the aesthetic of torture through the force-feeding chair, which became a vital instrument in President Obama's desire "not to let anyone die" in the hunger strike of 2013 in Guantanamo Bay. By sanctioning force-feeding through the rationale of keeping the body alive during the 2013 hunger strike, the 'chair' became ingrained in the aesthetic of power and the necropolitics of invasively keeping the terrorist body alive through torturous feeding rituals. Resistance of the inmates with and through their bodies in the hunger strike meant that their bodies became abstracted as a site for performing American imperial power. Underpinning a biopolitics of race and the sovereign power of the American empire and its new forms of slavery, the force-feeding chair symbolises the disciplining of the corporeal body through its modes of torture where the extraction of pain lends to the magnification and spectacle of imperial power (Scarry 1985). The sustenance of life through force-feeding during the hunger strikes speaks not about the sanctity of life but the violation of the detained bodies and the aestheticization of torture and its intrinsic tryst with biopower. The aesthetic of the force-feeding chair as an instrument of torture and pain performs to the pornography of American hegemony marking out the body of the Other as not possessing the right to death and to be held within a liminal state of bare life (yet one not worthy of death). As Bonnie Mann (2006, p.155) points out, 'superpower identity can only be maintained through its staging and re-staging of its own omnipotence, relying heavily on psychological (and corporeal) devastation through exemplary acts of sublime violence'.

In this paper, we discuss Guantanamo Bay as an interstitial site by examining the aesthetics produced through the complex interplay of the visible and the invisible with relevance to the force-feeding chair during the 2013 hunger strike. The chair within the regime of torture and incarceration is intimately implicated in the extreme disciplining and control of the "terrorist body" while legitimizing rituals of torture as part of the aesthetics of torture are enacted through legal struggles and ethical-medical debates about force-feeding. In the process, the chair as part of the arrangement and biotechnology of the camp, performs the necropolitics of American imperialism where torture over the corporeal body in Guantanamo Bay attests to the production of racialized and trapped bare life or 'living dead'. A life where its possibilities to end its enslavement through hunger strikes and death are thwarted and enacted as sites for performing imperial power. We analyse the performativity and aesthetics of the force-feeding chair through a discursive approach employing a combination of sources including newspaper articles, opeds smuggled out of Guantanamo by lawyers, affidavits and statements by lawyers, press releases issued by the Pentagon and speeches by ex-President Obama on force-feeding and its attendant accoutrements, specifically the restraint chair.

\section{Guantanamo Bay as an Interstitial Space}

The importance of reflecting on absences in a discussion on the "war on terror" has received attention from many scholars. As David Campbell (2011) has argued, "the visual culture of the 'war on terror' over the last ten years can be understood as both beginning and ending with absence." The lack of a visible battlefield is a distinct aspect of this war where propaganda, testimonials and revelations produce both fiction and a truncated visuality. Guantanamo Bay 
as a site of incarceration has an ambivalent and ambiguous visibility, and chosen specifically because it could be "out of sight, out of mind" (Purnell 2014). It is often invoked through a proliferation of official images (Van Veeren 2011) and propaganda under the banner of "war on terror". A closed visitation system which denies visitation rights to families and a lengthy application process for lawyers and the International Committee of the Red Cross (ICRC), as well as a vetting system for journalists, exacerbates this invisibility. The camp is also a legal "black hole" (Steyn 2004) where due process requirements can be avoided and as such is a site beyond the bounds of law (Bartosiewicz 2013) yet narrated through the proceedings of the American legal system. Equally, Guantanamo Bay as a "black site" is part of the American empire where covert prisons in eight countries including Afghanistan and Cuba were established by the CIA for the purposes of interrogation as part of the "war on terror". This practice of "outsourcing" prisoners to foreign countries for detention, interrogation, and sometimes trial, has come to be known, somewhat euphemistically, as "extraordinary rendition" (Sadat 2006, p.315). The US justified the site as necessary to detain exceptionally dangerous prisoners to interrogate them for additional intelligence information and prosecute them in military tribunals for war crimes (Bartosiewicz 2013). In multiple ways, current manifestations of imperial power have been materialised and normalized at Guantanamo (ReidHenry 2007).

When Barack Obama stepped down as president in January 2017 he handed over responsibility for 41 detainees still incarcerated in Guantanamo Bay to his successor. He succeeded in downscaling the camp but not closing it, despite repeated pledges to do so (see Caldwell 2014). Obama's plans to close the camp stalled when states refused to accept a maximum highsecurity prison in their jurisdiction, with Congress blocking the budget needed for detainee transfers or repatriations and the president declining to exercise the prerogative to a case-bycase waiver. As such, transfers and repatriation of men cleared for release stalled and they faced indefinite detention as political prisoners of Congress and the president (Frakt 2012). Significantly, US public opinion remained largely unchanged from 2009 to 2014 with twothirds opposed to the idea of moving detainees to US prisons (McCarthy 2014), thus relegating these racialized prisoners into a black hole infinitum.

Guantanamo Bay is a space of constant slippages between assertions by the Bush administration that the prisoners would be treated in a manner "consistent with" the Geneva Conventions without any assurance that the actions of the United States are subject to the Geneva Conventions (Gregory 2006, p.415). Produced through political discourse and yet unbound by international conventions on the treatment of prisoners of war, the camp is situated through the liminal. As an interstitial space of visuality between what is not directly witnessed and what is narrated through several sources (including personal testimonies, nongovernmental organization discourses, media portrayals and legal challenges) the site is constantly constructed and emerges through competing discursive spheres. Similarly, the forcefeeding chair as an artefact of carceral imagination provides an insight into the degree of control and discipline imposed on the corporeal body and the limitations of using the body as resistance. For Hannah Arendt (1966, p. 444), "there are no parallels to the life in the concentration camps. Its horror can never be fully embraced by the imagination for the very 
reason that it stands outside of life and death". As such, Guantanamo straddles within a social imaginary of being beyond representation and yet visualized and performed through symbols of torture and incarceration. In our ensuing discussions of the force-feeding chair, the biopower and biotechnologies coalesce with the exceptionalism of Guantanamo Bay where torture and pain are made manifest through violent body rituals

\section{The Racialized Body in the Camp}

Claudio Minca (2015, p.76) assigns Guantanamo a pivotal role in a broader geography of terror and "protective custody" implemented by the American empire. In Cuba but not of Cuba, the Guantanamo Bay detention enclave is there to remind us that the camp is still among us, almost as a totemic space of exception of the early twenty-first century, the pivot of a global archipelago of imprisonment where life is governed through direct and indirect means of violence (Minca 2015, p.76). Paul Gilroy (2004) implicates the camp within the functioning of the colonial political economies and where its origins can be traced. For Gilroy, beyond the historical, there is a functional connection between the camp and colonialism, nationalism, fascism as well as their biopolitics of race and culture (2004, p. 98). Agamben (1998) claims that the camp is the "nomos of our time" representing a new spatial archipelago of biopolitics intimately bound with biopower, violence and spatialities of exception. For Netz (2004, p.228), "history takes place as flesh moves inside space; it is thus, among other things, about the biology of flesh as well as about the topology of space".

Agamben's treatise on sovereign power locates the camp as the site of exceptionalism where citizenship can be suspected and the living can be ascribed as bare life. In the Nazi regime, the concentration camp assumed the function of an ideological technology producing the politics of the living dead encapsulated through the concept of the Muselmann (drawing from Primo Levi) to refer to half alive and half dead entities suspended between the material and ethereal worlds, not capable of belief or religion. As a liminal site between life and death, the camp becomes a site where the body and its worth is constantly tested. Netz postulates the camp guarded through barbed wire as intrinsic to the production of capitalist ecology targeting both animals and humans and in reconfiguring the relationship between them. As such, camps as sites of extreme control and governance become laboratories which birth a new kind of people, collapsing the distinction between man and animal. Camps then signify containment, violence and disciplining the corporeal body in terms of submission and control.

For Achille Mbembe (2003, p.11), the ultimate expression of sovereignty resides, to a large degree, in the power and the capacity to dictate who may live and who must die. Hence, to kill or to allow to live constitute the limits of sovereignty. To exercise sovereignty is to exercise control over mortality (2003, p.12). Mbembe constructs bare life as not a single production of biopower but through a combination of biopolitics, necropolitics and necropower. These then account for the various ways in which, in our contemporary world, weapons are deployed in the interest of maximum destruction of persons and the creation of death-worlds; new and unique forms of social existence in which vast populations are subjected to conditions of life 
conferring upon them the status of "living dead" (Mbembe 2003, p.40). For Mbembe, any historical account of the rise of modern terror needs to address slavery which enabled biopolitical experimentation en masse where the figure of the other appears through a triple loss: loss of a "home", loss of rights over his or her body, and loss of political status. This triple loss is identical with absolute domination, natal alienation, and social death (expulsion from humanity altogether) (2003, p.41)

Mbembe, drawing on Paul Gilroy, highlights "how there may be no reciprocity on the plantation outside of the possibilities of rebellion and suicide, flight and silent mourning, and there is certainly no grammatical unity of speech to mediate communicative reason. The slave is therefore kept alive but in a state of injury, in a phantom-like world of horrors and intense cruelty and profanity. As such, slave life, in many ways, is a form of death-in-life (2003, p.41). Colonial occupation itself was a matter of seizing, delimiting, and asserting control over a physical geographical area - of writing on the ground a new set of social and spatial relations. The writing of new spatial relations (territorialization) was, ultimately, tantamount to the production of boundaries and hierarchies (Mbembe 2003, p.26), zones and enclaves. Space is therefore the raw material of sovereignty and the violence it carried with it. Sovereignty meant occupation, and occupation meant relegating the colonized into a third zone between subjecthood and objecthood (2003, p.27). For Mbembe the contemporary forms of subjugation of life to the power of death (necropolitics) profoundly reconfigure the relations among resistance, sacrifice and terror.

As such, the camp signifies the threshold between life and death, where the qualification of a life worth living is constantly negotiated, reinvented, tested on real people and real bodies, where committing suicide in the camp or going on hunger strikes is considered an act of propaganda by the US military, and where force-feeding is crucial in avoiding death to keep control over bodies which are entrapped and become objects and subjects of imperial power. (Risen \& Golden 2006; Johnson \& Lubin 2013).

Guantanamo Bay theorized through Agamben's notion of a "state of exception" where norms and rules can be suspended and yet be characterized by the brutality of sovereign power. Similarly, it is classified as an "anomalous zone" (see Neuman 1996) where governments occasionally suspend fundamental norms within a territorially limited enclave in response to perceived necessity. In the process, Guantanamo appropriates a conflicted visuality where the aesthetic of torture emerges through the hidden, the revealed and the imagined. Derek Gregory (2004, p.405) points out that Guantanamo Bay depends on the mobilization of two contradictory legal geographies: one that places the prison outside the United States, allowing the indefinite detention of its captives; and another that places the prison within the United States in order to permit their "coercive interrogation". These interlocking spatialities, according to Gregory, implicate law and violence in complex and contorted ways. It is through its performative reductions, that the abstractions of geopolitics are folded into the intimacies of human bodies (Gregory 2006, p.415). As such, the "war on terror" produces an imagined geography in the site of the camp where a biopoliticized and racialized bare life is produced and enacted (Agamben 1998; Minca 2007; Gregory 2006). In our analysis, these enactments 
unfold specifically through the torture regimes of the force-feeding and the pain inflicted on trapped life and through this biotechnology and the necropolitics of the hunger strike.

\section{The Visuality of Torture}

The "aesthetic turn" in political thought draws attention to the "gap" between a form of representation and what is represented" rather than seeking to negate or deny it, viewing this lacunae as the very location of politics" (Bleiker 2001, p.510). As David Campbell (2007) highlights with the Darfur conflict, an aesthetic analysis goes beyond a critique of the gap between an image and its external referent where images perform as metaphoric symbols prompting affective responses and potential action. The aesthetic foregrounds the importance of visuality as well as its role in the construction of geographic imaginations and in the "functioning of geopolitical orders" (Hughes 2013, p.84). Visual economy, within this perspective, is understanding the significance of visuality for geopolitics (cf. Culcasi 2016; Campbell 2007) and sense-making about spaces (Dixon et al. 2012), both hidden and visible.

Since the late 20th century, aesthetic approaches expanded with a renewed interest in the qualities, capacities and vulnerabilities with the body locating it as the "very site and stuff of politics and source of new ethical encounters in the world" to interrogate dimensions power and emancipation (Hawkins \& Straughan 2016, p. 7). For French philosopher Jacques Ranciere $(2007 ; 2014)$, this aestheticization illuminate social hierarchies which order what can or cannot be seen or said, who can see or speak, and in the organization of space and time of what is understood to be intelligible. Embedded within this aesthetic regime are the excluded, the marginalized, the victimized and their attempts to disrupt the existing order. Political struggle is implicated in the aesthetic regime in its bid to reconfigure the social order within which certain groups and power dynamics are embedded (Dixon 2009 p. 415), revealing a politics of possibility and of malevolence (cf. Hawkins and Straughan 2016, p. 2).

In tandem, torture rituals can be a distinctive element of this aesthetic regime. Dorothy Roberts (2008 p.230) argues that torture plays a vital role in the violence needed to maintain white supremacy. Due to the history of US racialization by torture, the tolerance of state torture abroad can reinforce the domestic racial order that torture has helped to preserve. As such, torture's maintenance and production of racialized hierarchies can be linked to the current treatment of detainees in Afghanistan, Iraq, and Guantanamo to the status of African Americans in the United States. For Roberts, enslavement of human beings placed a category of people outside the ambit of humanity, giving the slaveholding class unrestrained license to inflict physical pain on their bodies (2008, p. 231). In tracing today's torture rituals back to lynchings, she contends that "by leaving disfigured black bodies hanging like 'strange fruit' from tree limbs, lynch mobs reinstated the white power structure threatened by Emancipation and Reconstruction" (2008, p. 232). Torture has the role of marking the bodies of its victims as 
subservient, humiliated, and degraded (2008, p. 233). The suspension of human rights and the creation of "obscure paralegal categories" such as "enemy combatants" to hold detainees indefinitely without the protections accorded to criminal defendants or prisoners of war, Roberts points out, mimics, reproduces and elongates colonial administration (2008, p. 240).

The construction of the "war on terror" as a new type of war negated the provisions accorded to the prisoners under the Geneva Conventions, rendering the terrorist as a stateless outlaw without a claim to protection. This provided an "exceptionalism" similar to the colonial regimes which marked African savages as uncivilized, justifying uncivilized use of torture in waging an imperialist war against them (Roberts 2008, p.241). Torture transforms its victims, rather than the perpetrators, into criminals and terrorists (Roberts 2008, p.243). The legal defence by the nation's highest officials of inhumane treatment in detention centres and the steady dose of torture in the media have acclimated the American public to the infliction of pain and degradation on racialized non-white bodies (Roberts 2008, p. 244). The body in the camp is pledged to new rituals of torture and experimentation, transgressing moral and sacred boundaries as a given.

According to Elaine Scarry (1985, p.27), "nowhere is the sadistic potential of language built on agency so visible as in torture. It represents a manifest and magnified act of inflicting pain. In the process, it creates a visibility to the pain as an interior subjective experience of another. What is incommunicable becomes expressed through torture, but pain is equally misappropriated to convey the 'spectacle' of power" (1985, p.27). The implements of torture through their implication with the tortured body form an associative visual bind. Scarry cites the examples of the prisoners of the Greek junta (1967-71) made to stare at the "wall arrangements of whips, canes, clubs and rods" (1985, p.27). Beyond pain, the lack of consent and the violation of the body's integrity makes force-feeding prima facie torture. Scarry points out that torture not only inflicts pain but objectifies it, making it visible to others and in so doing 'objectified pain' is not read as pain but as power (1985, p.28). The invisibility of pain is visualized through 'torture where it objectifies elements of pain into the insignia of power, and the conversion of the enlarged map of human suffering into an emblem of the regime's strength (Scarry 1985, p. 56). The force-feeding chair objectifies the invisibility of pain, presenting a means to visualise the torture and in the process it produces an incestuous relationship between pain, power and rituals of humiliation. The chair becomes emblematic in consistent re-enactments of the racialized other as a beast and beyond death, memorialising and invoking the "war on terror" as an ideology through material acts of torture.

The feeding chair needs to be contextualized through the hunger strikes in reaction to the dashed hopes after the promise of Obama's declaration to close the site. In early 2013, searches of the Quran and the confiscation of personal items including legal letters and family photos triggered a riot and the second largest hunger strike in the history of Guantanamo (Remes 2013). Hunger strikes have been documented in the camp even before the 2013 incident and were known to have occurred in 2002 when the men first arrived, and in 2005. The camp is also known to have detainees who are on long-term hunger strike. In July 2013, the protest peaked with 106 detainees on hunger strike with more than of half being force-fed, including men cleared for release (Lazara \& Rosenberg 2013). In December 2013, the Obama 
administration declared the hunger strike as "over" and refused to divulge the number of prisoners on hunger strike henceforth. Noticeably, the terminology associated with hunger strike and force-feeding changed during this period in the Obama administration. The term "hunger striker" was replaced with "noncompliant detainees" who engage in "non-religious fasts" and had to be "enterally-fed" (Crider 2014). The force-feeding chair and tubes became visual symbols of Guantanamo Bay under Obama and sat alongside those of iconic images of detainees in orange boiler suits.

\section{The Aesthetic of the Force-Feeding Chair}

The first public mention of a chair emerged when the New York Times reported in February 2006 that guards had "begun strapping recalcitrant" detainees in "restraint chairs" to prevent them "deliberately" vomiting (Golden 2006). The article mentioned that 25 restraining chairs, effectively "padded cell[s] on wheels" sent to Guantanamo had proven "highly effective" in breaking the hunger strike (Golden 2006). A letter to the Lancet highlighted that doctors working at Guantanamo had been force-feeding hunger strikers "strapped into restraint chairs" and through "techniques banned under international agreements" in March 2006 (Australian Doctor 2005). Images of the chair were not made public by the authorities. However, diagrams and illustrations from the manufacturer's operating manual for "emergency" or "safety" restraint chair (Safety Restraint Chair Inc. n.d.) were circulating on the internet and there were blogs explaining how easy it was to purchase one.

The manufacturer of the chairs, a small Iowa company, shipped five chairs worth US $\$ 1150$ each to Guantanamo on 5 December 2005 and 20 additional chairs on 10 January 2006. According to the manufacturer, these chairs are typically used in jails, prisons and psychiatric hospitals to deal with violent inmates or patients. The chair was seen by camp officials as highly effective in breaking the protest as the number of detainees on hunger strike plunged from 84 at the end of December 2005 to four. Official reports document that force-feeding was conducted in a "humane and compassionate manner" and only used when necessary to keep prisoners alive. The breaking of the strike through force-feeding was positioned as a moral question about keeping the prisoners alive and protecting their health.

With national and international criticism mounting over the continued detention and the forcefeeding of men in the 2013 hunger strike, President Obama maintained his stance that he did not want "any individual to die" (cf. Wittes 2013). Following, Obama's comments, the Pentagon for the first time in the history of Guantanamo made visible the technologies of forcefeeding. These included images of the feeding chair, enteral feeding tube, cans of nourishment and a hospital bed next to a shackle for restraining detainees unable to sit up during forcefeeding (Public Intelligence 2013). These images provoked international outrage among medical professionals, international media and human rights organizations as confirming the use of torture in Guantanamo leaving an indelible "stain" on Obama's presidency (Savage 2013b).

Force-feeding involves the feeding of a human or animal against their will with the insertion of a tube into the throat or nose through force. Triggering the body's natural gag mechanism, 
the body consequently has to be restrained through force or sedation. Concerns about forcefeeding being a form of punishment where the insertion of a large tube can cause bleeding and pain has been raised by the medical community (Elliott \& Whitaker 2006). Debilitating risks include major infections, pneumonia, collapsed lungs, heart failure and post-traumatic stress disorder (PTSD) (Reyes 1998). AMA deems force-feeding a contravention of their ethical codes for medical practitioners (Lazarus 2013). In 1975, the World Medical Association (WMA) prohibited the use of force-feeding where the prisoner is "capable of forming an unimpaired and rational judgement" and a violation of this can be deemed as torture. In tandem, the WMA and the American Medical Association (AMA) have condemned the force-feeding of prisoners, particularly when it is "accompanied by threats, coercion or physical restraint or any form of inhuman and degrading treatment" (Reyes 1998). Equally, medical ethicists are critical of the fact that the decision to force-feed a detainee can be decided by a non-medical personal (i.e., a camp commander) under Guantanamo's Standard Operating Procedures released to Al-Jazeera (Leopold 2013b). Subordination of the medical professional to the military imperative, in this case to force-feed detainees, is seen as a part of what has been called a new "military medical ethics" that emerged with the Gulf and Iraq wars (Miles 2013).

The official images and the captions and discourses released in early April 2013 sought to impose a clinical and sanitized frame on force-feeding, drawing on medical terminology of a "feeding chair", "enteral" tubing and cans of "nourishment". The narration of the procedure through medical technologies visible in any hospital or pharmacy sought to locate the instruments of "feeding" within minor medical procedures consistent with separate accounts by the camp medical officer of the insertion of the tube as "a quick in-and-out process" (AFP 2013). This act of "feeding" facilitated through a restraint chair was presented by the camp medical officer as a "humane treatment" (Savage 2013a) and detainee accounts of trauma from tubing (i.e. when the tube passes the back of the throat) were dismissed as "overblown" (AFP 2013).

According to the ICRC, force-feeding the detainees is a violation of Common Article 3 of the Geneva Convention that prohibits cruel, inhuman and degrading treatment. The Detainee Treatment Act of 2005 also prohibits it. The United Nations Human Rights Council (UNHCR) previously found that force-feeding used in earlier hunger strikes was torture under the United Nations Convention against Torture (UNCAT), a treaty to which the United States is a party. Though force-feeding can be a form of torture and a violation of internationally recognized human rights and medical ethics (Reyes 1998; Annas 2006), it is not a contravention in American law. While federal courts when asked to rule on hunger strikes have acknowledged that force-feeding may violate rights (rooted in the constitution and common law which afford inmates control over their bodies), the overriding concern of judges has been the impact of a likely death on the prison population. This has meant that the preservation of order in a prison has taken precedence over individual rights or consent (Legal Monitor Worldwide 2013). A federal judge accepted the argument of lawyers representing Guantanamo detainees that the procedure was a "painful, humiliating and degrading process" but one which could only be halted by the president (Savage 2013b). Obama in choosing not to prohibit force-feeding was 
heavily criticized in the international media and by UN experts on torture for sustaining the practice (Garvey 2013).

The portrayal of force-feeding as a clinical procedure through the use of medical terminology and the dismissal of the pain associated with the procedure was complemented through the showcasing of the empty chair as an effective biotechnology in preventing deaths. The disembodied chair as a spectacular for preserving life was presented uncoupled from its associated paraphernalia, such as the tubing feed, in the official photos. The empty chair in these official presentations sought to divorce the technology from its coercive function of subjugating the non-compliant or deviant terrorist body and inducing pain through the ritual of force-feeding and cell extractions where inmates are forcibly removed to be fed. The clinical framing of the disembodied chair focused instead on its life-sustaining qualities. Apart from the figures updated daily, there was little information on who was on hunger strike, being forcefed or hospitalized, as the camp authorities refused this information on the grounds that personal identifiers would contravene Geneva Convention prohibitions on "making a public spectacle" of prisoners, informing lawyers that their clients were being force-fed, post-event (Armbruster 2013; Fox 2013).

As Roberts points out, "the chain of racialized torture that spanned slavery, lynching, and police whippings remains unbroken in the brutalization of black suspects and inmates routinely carried out in today's criminal justice system" (2008, p.237). The force-feeding chair as a biotechnology of naked force and restraint needs to be contextualized against a precursory list of implements of torture which glorify the forceful restraint of the body, crossing the line from controlling the deviant body into rituals of sadistic torture and possession of the dispossessed. The restraint chair is intimately implicated in the control of the body in a prison system where "it locks prisoners" legs, arms, and torso with belts and cuffs, not only to control violent inmates but to sadistically punish those who challenge prison rules. Male and female prisoners have been strapped to the chair completely naked, gagged, hooded, beaten, pepper-sprayed, and left to die from asphyxia and blood clots. Inside the walls, the tool is aptly known as the "torture chair", "slave chair" and "devil's chair" (2008, p.237). Torture is instilled as a primary imagery of prisons through these physical restraints and by blocking prisoners' access to courts through federal legislation including the Anti-Terrorism and Effective Death Penalty Act of 1996 and the Prison Litigation Reform Act of 1995 (2008, p.237).

\section{Hunger Strikes in Guantanamo}

Guantanamo Bay is a space where the body of the incarcerated is possessed through the suspension of laws and the insertion of brutal modes of preserving enslaved life such that the body becomes both the source of torture and resistance. In addition to several long-term hunger strikers on almost continuous protest, three mass hunger strikes have been reported in 2002, 2005-2006 and 2013. With official refusal to release any information about the prisoners' protests, details have emerged through Freedom of Information requests, revealing that the mass hunger strikes had been "substantial, and at times, life-threatening" (Gutierrez 2005). In 
June 2006 three prisoners were found dead in their cells. All three men had been detained without trial for several years and none had court cases or military commissions pending, nor had they been charged. These three men had been on repeated hunger strikes, had been strapped into restraint chairs and force-fed by nasal tubes. The US deputy assistant secretary of state for public diplomacy described their deaths as "a Public Relations move to draw attention" and condemned it as "an act of asymmetric warfare against us" (Gregory 2006, p. 405). In March 2013, a group of detainees at Guantánamo Bay went on hunger strike. At the height of the protest 106 detainees refused to eat (Miller 2016) with reports of it emerging on Facebook and blogs run by legal representatives for the detainees (Remes 2013). While the camp authorities initially denied the situation, in mid-March 2013 they confirmed that 14 detainees were on hunger strike with six being tube fed and one hospitalized. The camp authorities continued to update these figures daily till December 2013 when they declared the protest over and discontinued reports. In this time period, the aesthetic of the force-feeding chair provided a means to situate the violence and violations over the bodies of the incarcerated through debates in court on force-feeding and leaks in social media and public spheres.

The body as a site for the spectacularization of state power has been explored in the writings of Foucault and Agamben. Foucault examined the spectacle of torture from the hidden prison regime to public events where the symbolic inflicting of pain became mediated through different modes of disciplining and controlling the corporeal body. The evolution of biotechnologies meant the body was no longer directly touched, with punishment implemented by an "army of technicians" including doctors charged with the denial of life rather than the inflicting of pain (Foucault 1976, p.19). In the modern penal regime, the body is no longer the "major target" of repression but control over the body manifests in different modes of disciplining, including constraints on liberties and rights (Foucault 1976, p.16, 18).

Agamben's critique of Foucauldian disciplinary power and politics rests on his conceptualization of bare life, positioned between political life and biological life. Stripped of political significance and denied political participation, "bare life" lies at the intersection of sovereign power and biopower. Excluded from political participation and stripped of significance, bare life is exposed to unchecked violence. Thus, bare life is vulnerable, expendable and endangered, occupying a "zone of indistinction and continuous transition between man and beast" (Agamben 1998, p.108). For Agamben, bare life is the counterpart to and target of sovereign violence, the "referent" and "effect" of it (Gregory et al. 2011).

Joseph Pugliese (2002) argues that the spacio-temporal logic of the camp induces "refugees to fall back on the one resource left to them in the midst of the violence of indefinite incarceration: their bodies. Even as the body is bounded and imprisoned, it can exercise a power that will elude the mechanisms of repression and the desire for absolute control". A hunger strike differs from other forms of abstinence in that it is a politically motivated appeal for justice where all other mechanisms have failed (Conlon 2013, p.135). The wasting body becomes that statement of an individual's deep sense of injustice, and while the hunger striker is not suicidal, they are willing to die if need be for their cause to be heard (Reyes 1998). Since the Suffragettes incorporated them into their repertoire of resistance before World War I, hunger strikes have become an internationally recognized mode of protest, particularly in prisons (Grant 2011). 
Hunger strikes in spaces of incarceration bring attention to the governance of the penal colony. Miller (2016) points out that corpses present a problem for they draw attention to the conditions of the camp and can be important in reshaping public opinion, as in the case of Bobby Sands in Northern Ireland. Sands was allowed to starve in a Northern Irish prison in 1981, and the images of his emaciated body still produce claims of political intransigence and cruel and unnecessary treatment at the hands of Margaret Thatcher's regime (Miller 2016, p.62). Miller (2016) argues that Sands metamorphosed from "terrorist" to martyr while the British state adopted the role of violent oppressor. Significantly, Sands' death sparked rioting throughout Northern Ireland, raising concerns about the treatment of Republican prisoners, and mediating the trajectory of Northern Irish politics throughout the 1980s. Hence, hunger strikes invoke the spectacular and invite moral condemnation. Hunger strikes have been a recurring form of protest in Guantanamo, revealing the quest to regain a measure of control over their own bodies by inmates. In 2013, these protests drew international attention to allegations of institutional torture and violence, seemingly supported by the Obama administration (Miller 2016).

Theorizations of the force-feeding tube as a form of disciplinary power have drawn on Foucault (cf. Anderson 2010; Anderson 2011) however the restraint chair has been under-explored other than $i$ the realm of medical ethics or in reconstructions outside the camp of its architecture with a view to making what is hidden from view public (Annas 2006 and Anderson 2011 respectively). We also address one of the limitations of Agamben in which his historical examples of bare life, including the Muselmanner, are diverse in terms of race, ethnicity and gender however his conceptualization does not explore the implications of diversity for different experiences of bare life (Ziarek 2008, p 93). Our analysis of the Guantanamo hunger strikers explores resistance to bare life by the racialized other and the state's escalating violence in response through the biopolitics of the chair. The chair as analysed in this paper challenges the implicit assumption in much of the literature that with force-feeding the body is acted upon and resistance ends when force-feeding begins (cf Lennon 2007; Mayhall 1995:324). The chair, or at least the images of it, also severs the Foucauldian link between the clinic and the prison created with the feeding tube that Anderson (2010) has explored. Originally designed to protect guards from violent, insane prisoners it recast the guards as the victims and the immobilized prisoner as the perpetrator. Much of the literature on hunger strikes has focused on the death fast and the ensuing martyrdom (Bargu 2014). However, the sadistic brutality of force-feeding as a form of reprisal for defying the state remains under-theorized (Ziarek 2008, p 99). The under-theorization is particularly notable at Guantanamo where the use of biotechnology and the medicalization of torture produce a visual economy and biopolitics of pain and torture under the banner of keep "bare life alive". The aesthetics of the chair does not deny a "the resistance of bare life but resistance to bare life", materialized in a willingness to die in a struggle for something valued as higher than life (Bargu 2014: 81).

The biopolitics of force-feeding is performative. In the visual interplay between the visible and invisible of Guantanamo, the body is entrapped in the liminal betwixt and between life and death where it is coded and inscribed with the repeated and torturous inserting of the tube as a ritual and the sustenance of stripped bare life through force feeding rituals as torture. The 
physical and symbolic branding of the body is instrumental in inscribing American biopower while marking out the body of the Other as not having the right to resist its denigration into bare life. The biotechnology of the chair enables torture to look scientific and mechanised, reframing bodily violations as a medical procedure. The pseudo-medical dynamics of the forcefeeding chair plays into an aesthetic of torture binding medical ethics with puritanical discourses of the preserving of life. This aesthetic invokes the performative, glorifying American imperial power feeding on the flesh and body of the incarcerated Other, condemned as not worthy of either life or death and suspended as Agamben's Muselmann or living dead.

\section{Force-Feeding the Deviant Body}

The use of restraint chairs started in 2005 after it was found that some hunger strikers were deliberately vomiting in their cells after having been tube-fed and that their health was growing precarious (see Golden 2006). The restraint chairs and the rituals of force-feeding that ensued marked out the extremes of control over the body of the Other. By the symbolic act of comingling their blood and bodily wastes through the routines of force-feeding, the inmates become collective and entrapped entities for torture where there is no individuation between bodies. Blood and bodily waste are spilled endlessly in these rituals and become both a weapon of torture and humiliation and means to condemn and control these racialized bodies. The pain of the condemned body is not recognized, neither is it reserved any sympathy, but becomes a canvass to constantly test the thresholds of pain and its attendant humiliation and compliance. Within this necropolitics, death is not an option, but the body, mind and its religion become sites of violence and constant transgression to mark their possession and submission to the imperial power.

In late 2005, General Bantz J. Craddock, the camp commander, announced that he was going to make it less "convenient" for prisoners to protest. Instead of leaving the $110-\mathrm{cm}$ tube to the prisoner's stomach in the nose for weeks on end, they began to insert and extract the tube twice a day using a thicker tube. Some have been subjected to the process more than 5000 times (Stafford Smith 2014). In the 2014 case of Imad Abdullah Hassan v Barack Obama, the testimony of the detainee detailed the use of thicker tubes and the practice of inserting and removing it twice a day. Strapped tightly in the restraint chair, the detainees were force-fed constipation drugs, causing them to defecate on themselves as they were restrained in the chair (New York Times 2014). The ritual of sitting on one's own faeces for up to two hours added to the humiliation (see Foreign Correspondent 2014) and the ritual of torture. The recurring theme of sitting with one's own bodily wastes and those of others is documented in testimonials, including the use of bloody feeding tubes which have not been cleaned after the last feed. "People with haemorrhoids would leave blood on the chair and the linens would not always be changed before the next feeding" (Stafford Smith 2014). They would be strapped down amid the faeces and blood for up to two hours at a time. The restraint chair and forcefeeding unleashed an aesthetics of violence conjoining inmates through their bodily fluids and wastes, casting them as one category of the condemned Other. The forced tubing and the pace at which the liquid was fed and its constancy or lack of it meant that the body reacted to these 
invasive procedures, often narrated as medically supervised. The vomiting body, the gagging body or the defecating body became a means to discipline other prisoners by showcasing their ordeal to other inmates. These humiliation rituals were designed as a deterrent to scare others into "not hunger striking" (Friedersdorf 2014).

John Protevi, qualifies those force-fed in prison as "trapped bare life" after Foucault and in drawing parallels to the "tube rape" of women prisoners who were force-fed despite being opposed to it $(2009$, p.127). The body of the incarcerated in the camps becomes a site of experimentation to induce "positive" behaviour. For instance, the force-feeding was combined with other forms of abuse such as lowering the temperature with the air conditioning or depriving the detainees of a blanket. This is particularly difficult for hunger strikers as they inevitably feel the cold more than someone who is eating. Detainees on hunger strikes were also refused the right to participate in communal prayers, and the prison-camp guards "would bang the cells all day and all night to prevent sleep" (Friedersdorf 2014). Lawyers for Muaz alAlawi argued at the Inter-American Commission on Human Rights that since their defendant had embarked on the hunger strike in 2013 he had "been subjected to escalating physical and psychological abuse from guards including solitary confinement and lack of access to prescribed medication while subjecting him to extreme temperatures in his cell" in addition to brutal force-feeding procedures (Worthington 2013). On the other hand, "compliant" hunger strikers can watch television while being force-fed seated on a normal soft chair rather than the restraint chair and they can choose between different flavours of the nourishment fed through the tube (Agence France Presse 2014). Non-compliant ones are strapped in a restraint chair and fitted with a "spit shield" to stop them spitting at guards (AFP 2014).

Dr Steven Miles, an expert witness in the case of Dhiab v Obama brought by Jihad Ahmed Mujstafa Diyab in 2014, argued that the camp authorities were "applying ill-advised procedures as a form of punishment" (Yost 2014). For instance, the authorities had been lubricating the tube with olive oil instead of a water-soluble lubricant. With olive oil, there is a risk of it dropping into the lungs and causing an inflammatory reaction (Nocera 2014). He concluded that they had turned a medical procedure into a penal strategy reminiscent of "a practice of torture called 'Water Cure' that has been practiced since the Middle Ages" (Targeted News Service 2014b). One prisoner contracted a chest infection as a result of alleged "botched forcefeeding procedures" resulting in him vomiting blood and losing consciousness (Targeted News Service 2014a).

The ritual of force-feeding is supplemented through another coercive technique of forced cell extraction. Letters received from legal charity Reprieve say British resident Shaker Aamer had been "reportedly beaten" as a form of "crackdown on prisoners protesting detention without charge" (Common Dreams 2014). Forced cell extraction (FCE) has been described as a "highly orchestrated procedure" in which a five-man riot squad in armour pins the detainee to the floor, shackles him and carries him out of his cell to a restraint chair where he is strapped in. One soldier holds the detainee's head, while another feeds a tube into his nose and down his stomach (Nocera 2014). The authorities defended these techniques on the basis that inmates were abusive to guards or threatened to kill or seriously harm them (Boyle 2014). 
Guantanamo as an interstitial space between the revelatory and the suppressed became evident again when lawyers in the case of Diyab requested videos of these forced cell extractions and force-feeding to document a period of particularly "gratuitous brutality." The US government in 2015 released eight redacted videos of force-feeding to the court as part of the case. Lawyers claimed this footage was "hard to watch" (AFP 2014). The existence of the tapes emerged after Diyab filed a lawsuit over the forced-feeding procedure and the lawyers along with a consortium of newspapers sued for videos to be made public. Camp authorities stopped making the recordings after they were ordered to turn them over to the court (Legal Monitor Worldwide 2014). The US government has resisted making the tapes public, arguing that although the tapes depict only "lawful, humane and appropriate" behaviour, the public is not used to seeing images of men strapped down for force-feeding, and releasing them would cause outrage, harm national security and endanger US soldiers abroad (New York Times 2014). The Pentagon has been resistant to public access of these tapes as they are classified under the general banner of protecting national security and could be used as propaganda against the US government.

The hunger strike also prompted more invasive and humiliating body searches. From February 2013 guards began "extremely aggressively searching their privates" in response to a mentally ill detainee committing suicide. The authorities justified the searches on the grounds of preventing the flow of "contraband" (Green \& Rosenberg 2013). It was one of the several new strict protocols introduced after the start of the mass hunger strike in 2013 (Leopold 2013b). It was seen by the lawyers as a form of "religious humiliation", "sexual assault" and a "disgusting tactic", designed to break the hunger strike (Cahalan 2013). It also signified a departure from a 2009 defence department review of conditions at Guantanamo which had upheld that "due to cultural sensitivities" guards are not allowed to conduct frisk searches of the groin area and are limited to grasping the waistband of the detainees' trousers and shaking their pants. In addition, searches of the Quran are also not permitted. Lawyers reported that prisoners were emotionally disturbed by having their "genitals groped" and that some of the guards were conducting it in a way that was vindictive (Leopold 2013a)

All the hunger strikes at Guantanamo were triggered by some perceived disrespect or desecration of the Quran, including the hunger strike in 2013. The body and its religion became a site of propaganda and torture at the camp. The supplements used in force-feedings were marked as both kosher and halal, to impress the "culturally correct tube feedings" (Rosenberg 2013). This was juxtaposed against the military adopting the use of "deliberate desecration" of the Quran as a form of torture in the "war on terror" (Peppard 2008). These practices, dating from the Kandahar detention facility in 2002, could be found across the black sites but reached new levels in the early years of Guantanamo. A report on FBI involvement in detainee interrogation found desecration was one of the most frequently reported offenses, and FBI documents made public reported accounts that guards "flushed a Koran in the toilet" two months after the Pentagon had outlined a policy for respecting religion (Bazelon et al. 2006). The constant transformation of the sacred into the profane as evidenced in these instances of desecration, and equally the employment of bodily waste to denigrate the detainees, meant that religious liberties and the corporeal body were marked out for violence and in consecrating the sacred in the camp site. The force-feeding chair, couched as humane and keeping the "non- 
compliant" terrorist alive, forges an intimate, violent relationship with the corporeal bodies of the detainees, their bodily wastes and blood. Co-mingling them through their blood and faeces and equally through their pain to produce a racialized bare life. The force-feeding chair, like other historical implements of torture, appropriates an indexicality of ascribing the body of the racialized detainees as marked out for the production of violence, torture and productive pain to communicate the spectacle of American imperialism and power in the black sites which subsume the sacred and enact the camp through depravity both in terms of humanity and spirituality.

\section{Conclusion}

An aesthetics of the force-feeding chair used at the nominally hidden Guantanamo site spectacularizes torture and the celebration of American imperial power. At Guantanamo there is a visual economy at work where the chair operationalises torture through an interplay of the visual, invisible, image and discourse. The aesthetic of the force-feeding chair, the extractions from the cell to force-feed, as well as the routines of force-feeding itself play out through official discourses, testimonials and through courts as a struggle for human rights and against the violation of the body and its religious beliefs. These reveal that the Cartesian duality of the mind and body of the "monster" terrorist become completely possessed by the prison authorities. On the one hand, Guantanamo is created for extracting confessions of terrorism, and on the other hand, their bodies must be kept alive during their indefinite incarceration. Their religion becomes a tool that is used to provoke and traumatise them psychologically in constantly transgressing the sacred. The necropolitics of keeping them alive means they become living corpses where their bodies are kept alive but stripped of religion, dignity and thwarting their agency to protest with and through their bodies. In the process, they become Agamben's Muselmanner, trapped between life and death yet not capable of sustaining the sacred as evidenced through desecration of the Quran in the camp. As Derek Gregory points out, here the sovereign power is at its most naked where inmates are reduced to bare life. With all legal protections removed they are enacted as something less than human (Gregory 2006, p.414).

\section{References}

AFP, 2013. Force-fed "torture" or humane treatment at Guantanamo? August 12

AFP, 2014. US judge hears of Guantanamo force-feeding techniques. October 09.

Agamben, G., 1998. Homo Sacer: Sovereign Power and Bare Life, Stanford, California: Stanford University Press.

Anderson, P., 2011. Architecture is not justice: See Guantanamo Bay. In R. Rivera-Servera \& H. Young, eds. Performance in the Borderlands. Palgrave Macmillan, pp. 82-96..

Anderson, P., 2010. So Much Wasted: Hunger, Performance, and the Morbidity of 
Resistance, Durham and London: Duke University Press.

Annas, G.J., 2006. Hunger Strikes at Guantanamo - Medical Ethics and Human Rights in a "Legal Black Hole." The New England Journal of Medicine, 355(15), pp.1377-1382.

Anon, Safety Restraint Chair Inc. https://restraintchair.com/

Arendt, H., 1966, The origins of totalitarianism. New York: Harcourt \& Brace

Armbruster, B., 2013. The Inside Story Of The Hunger Strike And Force-Feeding At

Guantanamo. ThinkProgress. Available at: https://thinkprogress.org/the-inside-story-ofthe-hunger-strike-and-force-feeding-at-guantanamo-f93708bfc89b/

Australian Doctor, 2005. Doctors defend hunger strikers' rights. May 03

Bargu, B., 2014. Starve and Immolate: The Politics of Human Weapons, New York: Columbia U.

Bartosiewicz, P., 2013. The Miami Herald's Carol Rosenberg on How to Report From Guantanamo Bay. Daily Intelligencer. Available at: http://nymag.com/daily/intelligencer/2013/02/carol-rosenberg-reporting-fromguantanamo-bay.html.

Bazelon, E., Carter, P. \& Lithwick, D., 2005. What Is Torture? Slate. 26 May https://slate.com/news-and-politics/2005/05/what-is-torture.html

Bleiker, R., 2001. The Aesthetic Turn in International Political Theory. Millennium: Journal of International Studies, 30(3), pp.509-533.

Boyle, D., 2014. Obama administration moves to keep hearing into treatment of force-fed Guantanamo inmate secret. MailOnline. 29 September https://www.dailymail.co.uk/news/article-2773869/Administration-seeks-close-Gitmohearing.html

Cahalan, P., 2013. Guards are sexually assaulting me, says the last Briton in Guantanamo. The Independent. $31 \mathrm{July}$ https://www.independent.co.uk/news/world/americas/guardsare-sexually-assaulting-me-says-the-last-briton-in-guantanamo-bay-8740739.html

Caldwell, P., 2014. Obama is supposedly getting ready to close Gitmo. Here are 9 other times we have heard that. Mother Jones [Blog]. Available at:

http://www.motherjones.com/politics/2014/10/obama-supposedly-getting-ready-closeguantanamo-just-every-year-his-presidency.

Campbell, D., 2007. Geopolitics and visuality: Sighting the Darfur conflict. Political Geography, 26, pp.357-382.

Campbell, D., 2011. From Absence to Absence: The Visual Culture of The 'War on Terror.' E-International Relations, 09 Novembe. Available at: http://www.eir.info/2011/11/09/from-absence-to-absence-the-visual-culture-of-the-'war-on-terror'/.

Common Dreams, 2014. Washington: Shaker Aamer "Beaten" in Latest Guantanamo Crackdown. 27 August. https://www.commondreams.org/newswire/2014/08/27/shakeraamer-beaten-latest-guantanamo-crackdown 
Conlon, D., 2013. Hungering for freedom: Asylum seekers' hunger strikes - rethinking resistance as counter-conduct. In D. Moran, N. Gill, \& D. Conlon, eds. Carceral spaces : Mobility and agency in imprisonment and migrant detention. New York and London: Routledge, pp. 133-148.

Crider, C., 2014. Gitmo hunger strikes are a cry for help. Why is the US fighting back with secret torture? The Guardian. Comment is Free. Available at: www.theguardian.com/commentisfree/2014/sep/30/gitmo-hunger-strikes-secret-forcefeeding.

Culcasi, K., 2016. Images and Imaginings of Palestine: Territory and Everyday Geopolitics for Palestinian Jordanians. Geopolitics, 21(1), pp.69-91.

Dixon, D., 2009. Creating the semi-living: on politics, aesthetics and the more-than-human. Transactions of the Institute of British Geographers, 34, pp.411-425.

Dixon, D., Hawkins, H. \& Straughan, E., 2012. Of human birds and living rocks: Remaking aesthetics for post-human worlds. Dialogues in Human Geography, 2(3), pp.249-270.

Elliott, F. \& Whitaker, R., 2006. Shameful: This is the world's view on Guantanamo. But Tony Blair still calls it "an anomaly." The Independent on Sunday. 19 February https://www.independent.co.uk/news/world/politics/shameful-this-is-the-worlds-viewon-guantanamo-but-tony-blair-still-calls-it-an-anomaly-6108802.html

Foreign Correspondent, 2014. Inside Gitmo. ABC. 29 April https://www.abc.net.au/foreign/inside-gitmo/5419426

Foucault, M., 1976. Discipline and Punish: The Birth of the Prison. New York: Pantheon

Fox, B., 2013. US now naming force-fed Guantanamo prisoners. Associated Press. April 08

Frakt, D., 2012. Prisoners of Congress: The constitutional and political clash over detainees and the closure of Guantanamo. University of Pittsburgh Law Review, 74, pp.179-262.

Friedersdorf, C., 2014. A Gitmo Prisoner Alleges He Has Been Tortured Under Obama. Atlantic Online. 12 March. https://www.theatlantic.com/politics/archive/2014/03/agitmo-prisoner-alleges-he-has-been-tortured-under-obama/284369/

Garvey, K., 2013. Feeding torture; Criticism grows of Obama's willingness to force-feed prisoners at Guantanamo Bay who are on a hunger strike. National Post (Canada). June 29

Gilroy, P., 2004. Between camps: Nations, cultures and the allure of race, London and New York: Routledge.

Golden, T., 2006. Tough U.S. Steps in Hunger Strike at Camp in Cuba. New York Times. Available at: http://humanrights.ucdavis.edu/projects/the-guantanamo-testimonialsproject/testimonies/prisoner-testimonies/tough-u-s-steps-in-hunger-strike-at-camp-incuba.

Grant, K., 2011. British suffragettes and the Russian method of hunger strike. Comparative Studies, 53(1), pp.113-143.

Green, D. \& Rosenberg, C., 2013. How Ramadan Affects Guantanamo Bay Detainees’ 
Hunger Strike. NPR. June 17

Gregory, D., 2004. The Colonial Present, Afghanistan, Palestine, Iraq, Malden MA and Oxford: Blackwell.

Gregory, D., 2006. The Black Flag: Guantánamo Bay and the Space of Exception.

Geografiska Annaler Series B Human Geography, 88, pp.405-427.

Gregory, D. et al. eds., 2011. Space of exception. In The Dictionary of Human Geography. John Wiley \& Sons.

Gutierrez, G., 2005. The Guantánamo Prisoner Hunger Strikes \& Protests: A Special Report By the Center for Constitutional Rights,

Hawkins, H. \& Straughan, E. eds., 2016. Geographical Aesthetics: Imagining Space, Staging Encounters, London and New York: Routledge.

Hughes, R., 2013. Geopolitics and visual culture. In The Routledge Research Companion for Critical Geopolitics. pp. 69-88. London and New York: Routledge

International New York Times, 2014. Release the force-feeding videos. December 09

Johnson, R. \& Lubin, G., 2013. Why the military force-feeds detainees at Guantanamo Bay. Business Insider. Available at: http://www.businessinsider.com/forcefeeding-detaineesat-guantanamo-bay-2013-4.

Lazara, G. \& Rosenberg, C., 2013. Tracking the hunger strike. Miami Herald. Available at: http://www.miamiherald.com/static/media/projects/gitmo_chart/.

Lazarus, J.A., 2013. Physicians' ethical obligations to hunger strikers. BMJ: British Medical Journal, 3705(June), pp.1-2.

Legal Monitor Worldwide, 2013. In force-feeding detainees, Obama has courts on his side. 28 May

Legal Monitor Worldwide, 2014. Gitmo authorities have stopped filming force-feeds, lawyers say. June 16

Leopold, J., 2013a. Guantanamo genital searches to continue - Al Jazeera English. AlJazeera. 09 July https://www.aljazeera.com/humanrights/2013/07/201371893153946602.html

Leopold, J., 2013b. Revised Guantanamo force-feed policy exposed. Al-Jazeera. Available at: http://www.aljazeera.com/humanrights/2013/05/201358152317954140.html.

Lennon, K., 2007. Fasting for the public: Irish and Indian sources of Marion Wallace Dunlop's 1909 hunger strike. In Enemies of Empire: New erspectives on imperialism, literature and historiography. pp. 19-51. Dublin and Portland OR: Four Courts Press

Mann, B. (2006), How America Justifies Its War: A Modern/Postmodern Aesthetics of Masculinity and Sovereignty. Hypatia, 21: 147-163. doi:10.1111/j.15272001.2006.tb01132.x

Mayhall, L., 1995. Imagination, Creating the "suffragette spirit": British feminism and the historical. Women's History Review, 4(3), pp.319-344. 
Mbembe, A., 2003. Necropolitics. Public Culture, 15(1), pp.11-40.

McCarthy, T., 2014. CIA torture program: Senate report details abuse of detainees - as it happened The Guardian. 09 December https://www.theguardian.com/usnews/live/2014/dec/09/cia-torture-report-released-senate

Miles, S.H., 2013. The new military medical ethics: Legacies of the gulf wars and the war on terror. Bioethics, 27(3), pp.117-123.

Miller, I., 2016. A History of Force Feeding: Hunger Strikes, Prisons and Medical Ethics, 1909-1974, Basingstoke: Palgrave Macmillan..

Minca, C., 2007. Agamben's geographies of modernity. Political Geography, 26(1), pp.7897.

Minca, C., 2015. Counter-camps and other spatialities. Political Geography, 49, pp.90-92. Available at: http://dx.doi.org/10.1016/j.polgeo.2015.09.003.

Netz, R., 2004. Barbed Wire: An Ecology of Modernity, Durham: Wesleyan University Press.

Neuman, G.L., 1996. Anomalous zones. Stanford Law Review, 48, pp.1197-1234.

Nocera, J., 2014. The Guantánamo Tapes. The New York Times. June 03

Peppard, M., 2008. The Secret Weapon. Commonweal, 135(21), p.11.

Public Intelligence, 2013. Guantanamo Joint Medical Group Hunger Strike Response Photos. Available at: https://publicintelligence.net/guantanamo-hunger-strike-response-photos/ [Accessed February 9, 2017].

Protevi, J., 2009. Political affect: Connecting the social and the somatic, Minneapolis and London: University of Minnesota Press.

Pugliese, J., 2002. Penal Asylum: Refugees, Ethics, Hospitality. Borderlands, 1(1). Available at: http://www.borderlands.net.au/vol1no1_2002/pugliese.html.

Purnell, K., 2014. Body politics and boundary work: Nobodies on hunger strike at Guantanamo (2013-2015). Alternatives: Global, Local, Political, 39(4), pp.271-286.

Ranciere, J., 2007. The politics of aesthetics: The distribution of the sensible Gabriel Rockhill. (tr), London: Continuum Publishing.

Ranciere, J., 2014. Figures of history, Cambridge: Polity Press.

Reid-Henry, S. 2007. Exceptional Sovereignty? Guantanamo Bay and the Re-Colonial Present. Antipode. 39(4) pp 627 - 648

Remes, D., 2013. Letter from Centre for Constitutional Rights. Available at: http://ccrjustice.org/sites/default/files/assets/files/2013_03_04_Ltr_JTF_Smith_Welsh.p df.

Reyes, H., 1998. Medical and Ethical Aspects of Hunger Strikes in Custody and the Issue of Torture. Research in Legal Medicine, 19(1). Available at: http://www.icrc.org/eng/resources/documents/article/other/health-article-010198.htm. 
Risen, J. \& Golden, T., 2006. 3 Prisoners commit suicide at Guantanamo. New York Times. Available at:

http://www.nytimes.com/2006/06/11/us/11 gitmo.html?pagewanted1/4all\&_r1/40.

Roberts, D., 2008. Torture and the biopolitics of race. University of Miami Law Review, (229). Available at: http://repository.law.miami.edu/umlr/vol62/iss2/4.

Rosenberg, C., 2013. Guantánamo's culturally correct tube feedings. Miami Herald.

Available at: http://www.miamiherald.com/news/nation-

world/world/americas/guantanamo/article3620683.html.

Sadat, L.N., 2006. Ghost Prisoners and Black Sites: Extraordinary Rendition under International Law. Case Western Reserve Journal of International Law, 37, pp.309-342.

Savage, C., 2013a. Food refusal rises among detainees at Guantánamo. The International Herald Tribune. March 21

Savage, C., 2013b. Judge urges president to address prison strike. New York Times.

Scarry, E., 1985. The Body in Pain: The Making and Unmaking of the World, New York and Oxford: Oxford University Press.

Stafford Smith, C., 2014. Gitmo hunger striker v. Barack Obama. Yemen Times. March 18

Steyn, J., 2004. Guantanamo Bay: the legal black hole. The International and Comparative Law Quarterly, 53(1), pp.1-15.

Targeted News Service, 2014a. Guantanamo Detainee Reveals Escalating, Brutal Punishment of Hunger Strikers. Available at:

http://www.reprieve.org.uk/press/2014_05_13_pub_guantanamo_brutal_punishment/.

Targeted News Service, 2014b. Guantanamo Prisoner Launches Historic Legal Challenge to Force-Feeding Abuse. Available at:

http://www.reprieve.org.uk/press/2014_03_11_guantanamo_forcefeeding_challenge.

Van Veeren, E., 2011. Captured by the camera's eye: Guantánamo and the shifting frame of the Global War on Terror. Review of International Studies, 37(04), pp.1721-1749.

Virilio, P., 1980. The Aesthetics of Disappearance. (tr) P. Beitchman. Los Angeles:

Semiotext(e)

Wittes, B., 2013. The President's Guantanamo Comments. [Blog]. Lawfare. April 30. https://www.lawfareblog.com/presidents-guantanamo-comments

Worthington, A., 2013. Watch the Shocking New Animated Film About the Guantánamo Hunger Strike. [Blog]2. Available at:

http://www.andyworthington.co.uk/2013/10/13/watch-the-shocking-new-animated-filmabout-the-guantanamo-hunger-strike/.

Yost, P., 2014. Doctor says Gitmo practices ill-advised. The Associated Press. Available at: https://www.usnews.com/news/politics/articles/2014/10/07/physician-gitmo-practicesill-advised.

Ziarek, E.P., 2008. Bare Life on Strike: Notes on the Biopolitics of Race and Gender. South 
Atlantic Quarterly, 107(1), pp.89-105. 